\title{
THE ROLE OF MARKETING INFORMATION SYSTEMS (MKIS) IN SERVICE QUALITY IN ETHIOPIAN INDUSTRIES
}

\author{
E. Berhan ${ }^{1} \&$ D. Kitaw ${ }^{2}$ \\ 1,2 Department of Mechanical Engineering (Industrial Engineering Stream) \\ Addis Ababa Institute of Technology (AAiT), Addis Ababa University, Ethiopia \\ ${ }^{1}$ eshetie_ethio@yahoo.com; ${ }^{2}$ danielkitaw@hotmail.com
}

\begin{abstract}
This paper deals with the role of marketing information systems for service quality in Ethiopian industries in terms of their IT infrastructure, data acquisition, information processing, business function, and service quality. A quantitative survey of 42 Ethiopian industries in 2009 indicated that most of these industries are dominated by noncomputerised information systems. The data acquisition and IT infrastructure strongly support the information process. Information processing significantly and positively predicts both service quality and business function. But the business function that uses processed data and information for its activities - such as planning, decision-making, and implementation - is not found to be a significant predictor of service quality.
\end{abstract}

\section{OPSOMMING}

In hierdie artikel word die rol van bemarkingsinligtingstelsels by diensgehalte in Etiopiese industrieë bespreek in terme van hul IT-infrastruktuur, datavaslegging, inligtingsprosesseervermoë, operasionele funksionering en diensgehalte. 'n Kwantitatiewe opname onder 42 Etiopiese industrieë is in 2009 onderneem. Dit het getoon dat die meeste van hierdie industrieë gedomineer word deur nie-rekenaargebaseerde inligtingstelsels. Die datavaslegging en IT-infrastruktuur ondersteun die inligtingsproses. Inligtingsprosesseervermoë voorspel betekenisvol en positief wat die diensgehalte sal wees. Daarteenoor is gevind dat die operasionele funksionering wat verwerkte data en inligting aanwend vir aktiwiteite soos beplanning, besluitneming en implementering nie ' $n$ indikator van diensgehalte is nie.

\footnotetext{
1 The author is a PhD student in Industrial Engineering in the Department of Mechanical Engineering, Addis Ababa institute of Technology (AAiT), Addis Ababa University, Ethiopia.
} 


\section{INTRODUCTION}

In today's business market, almost all companies face an ever-changing and highly competitive environment [2]. In order to meet or exceed their customers' expectations, the business function of any organisation (such as marketing) has to use information systems (IS) as a tool. The business function is responsible for identifying the customers' need, either stated or implied, and for passing this on to the design department so that specifications meet customer requirements. All the other functional units in the organisation also become involved [37]. Moreover, companies face a rapidly-changing marketing environment and greater competition [15]. This, in turn, may call for the systematic organisation of a large amount of data to support the decision-making process. As a result, the marketing information system based on information technology (IT) has become a common management decision-making tool in organisations [16, 35]. The use of IS- and IT-based marketing information systems improves the quality of service; and service quality is also a determinant of customer satisfaction for any organisation [26].

The marketing information system (MKIS) has received considerable attention as a tool for marketers in many organisations since the 1990s [23, 21, 15, 16, 35, 36]. Nevertheless, its role has been limited in many Ethiopian industries, and particularly its importance as a tool in the business function for timely and accurate decision-making. Moreover, developing and sub-Saharan African countries like Ethiopia currently have the least-developed communication networks in the world [1]. This has increased the formidable challenges that globalisation has brought to developing countries as they struggle to compete in world markets $[14,5]$.

Due to poor infrastructures for communication and information technology, Ethiopian industries have information systems that do not adequately support their marketing activities. This has an adverse effect on their provision of quality services. The UNDP Ethiopia Newsletter [34] states: "Ethiopia should restructure its Telecom and Information and Communication Technology (ICT) sectors to encourage innovation, broaden access to ICT and provide a better infrastructure for the development of entrepreneurship and the achievement of national policy objectives". Furthermore, Harrison [13] states that ICT in Ethiopia has required special attention compared with its other service sectors. Thus, the frail ICT sector affects information-based marketing decision-making activities. There have been national conferences and seminars on communication technology in Ethiopia, but no studies have been conducted to address this problem. The aim of this study, therefore, is to assess the role of MKIS in service quality in Ethiopian industries.

This paper first presents the methodology of the research and the conceptual framework. This is followed by a literature review on MKIS and its role in service quality. The results and a discussion of the quantitative survey of 42 industries are presented, followed by the conclusion.

\section{RESEARCH METHODOLOGY}

A quantitative survey with a semi-pre-coded standardised questionnaire was used to collect data for the research. For the purposes of this study, 150 enterprises with a fairly similar scale of economy [39] were randomly selected from a list obtained from the Addis Ababa Chamber of Commerce (AACC). The questionnaires were filled in by employees with at least one year's experience in the field of marketing information systems, information systems, or marketing management. The items in the questionnaire were measured using a 5-point scale ranging from 'strongly disagree' (1) to 'strongly agree' (5). The population was categorised into three groups that were assumed to be homogeneous: production (64 industries); service (76 industries); and other sectors (10 industries). After conducting a pre-questionnaire test on five industries, the questionnaire was distributed to 65 enterprises that were proportionally selected from the three groups above. Of these 65 enterprises, 42 industries (19 enterprises from production, 20 from service, and 3 from other sectors) filled in and returned the questionnaire with a respondent rate of $64.6 \%$. The 
sample size ( 42 industries) accounts for $28 \%$ of the total population of 150 . The quantitative data was purified and analysed using SPSS version 19. SPSS and AMOS18 were used to analyse the confirmatory factor analysis, reliability test, descriptive statistics, Pearson correlation, and path analysis.

\section{LITERATURE REVIEW}

\subsection{MKIS and service quality}

The use of computers, and thus the development and awareness of mechanisation, is closely related to the introduction of computers in Ethiopia by foreign suppliers in the 1960s [34]. In 1961 the Ethiopian Air Line (EAL) was the first to introduce a modern management information system to simplify work and process data. After EAL, the Ethiopian Electric Light and Power Authority (EELPA) was a major user of IT to support its service from 1964. They mainly used IT in their accounting and inventory systems of payroll and billing; their data processing department considered this a major achievement. In 1981 the Ethiopian Science and Technology Commission [9] conducted a survey of 63 libraries and information centres to assess information services in the country. Apart from the documentation centres of international and government organisations and the Development Project Study Consultancy Agency (DPSCA), no other institutions - public or private - were found to have automated their services. During the earliest phase of the introduction of ICT in Ethiopia, its growth remained static or sluggish compared with the development of ICT in developed countries [13]. Thus most Ethiopian industries continued to process information manually.

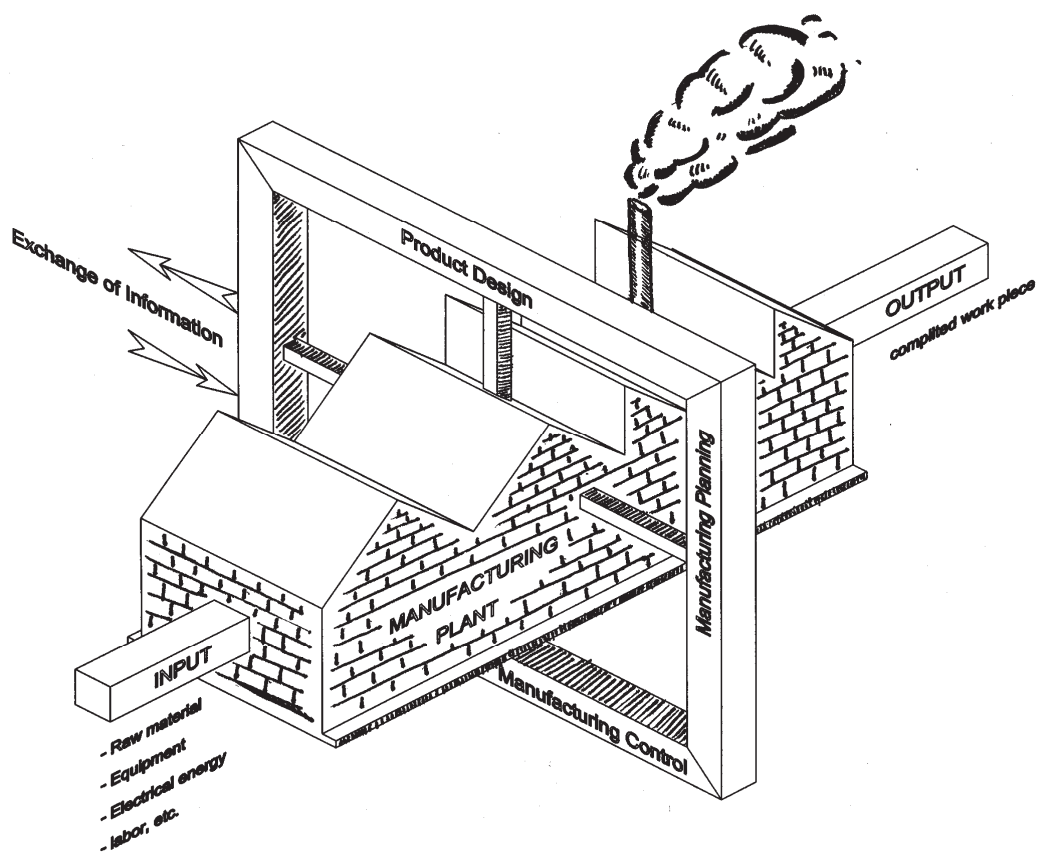

Figure1: The information processing cycle in a typical manufacturing firm [6]

This manual system of information-gathering, analysing, processing, and disseminating made businesses dysfunctional and handicapped their operations. The need for, and application of, information systems is an inevitable fact; it is the 'nerve centre' of today's enterprises. The high speed of global change in IT - and in competitive strategy - has caused a dramatic change in the application of IT [24]. Globalisation is often seen as an impersonal and inevitable force, with markets driven into 'going global' by a dramatic increase in the adoption of ICT [5, 14, 38]. Soon after the management information system 
(MIS) concept was formed in the mid-1960s, marketing applied it to its own information needs, creating a formal system called the MKIS [10, 21, 22, 38]. MKIS is a computerised system designed to provide an organised flow of information that enables and supports the marketing activities of an organisation [31, 23].

Nowadays, due to unprecedented global competition, organisations are required to gather, analyse, process, and disseminate large amounts of data for timely and effective decisionmaking. Computerised systems enable proper storage and analysis, and the processing and dissemination of accurate, reliable, and timely information [16, 20]. Furthermore, it creates an environment that allows a business to communicate with the outside world (its customers) and to provide quality service. As Albert et al. [3] and Niza et al. [26] argue that service quality has been found to be an important input (among others) for customer satisfaction. They are, therefore, the beginning and end of the information-processing cycle. Some of the activities included in business functions are sales and marketing, sales forecasting, order entry, cost accounting, and customer billing [6], as shown in Figure 1. MKIS thus enables the integration of marketing activities and customer service [31, 16, 23]. The survival of a business is highly dependent on the advantageous opportunities offered by modern IS and IT [16] through its MKIS. In this regard, it becomes one of the basic tools for business functions to provide quality service.

According to Terrence et al. [32], MKIS can be a tool that supports managers in their marketing decision-making by providing integrated links between functional departments or divisions. Spros et al. [31] and George et al. [11] emphasise that companies that offer ITbased marketing decisions will see a significant impact on their quality of service. IT-based MKIS will largely impact on customer operations, thus affecting the quality of service. According to Albert et al. [3] and Parasuraman et al. [28], service quality is shaped by the comparison that customers make between their expectations about a service and their perception of the way the service has been performed. Pitt et al. [29] stated that the effectiveness of IS is partly assessed by its ability to provide quality service to its users. If a company does not have MKIS, its efficiency and effectiveness are likely to be severely degraded and its competitive edge weakened [24]. However, making timely and pertinent decisions characterised the function of any MKIS [37, 38]. But, as the competition intensified, the gathering and management of marketing information became increasingly important [24, 38]. As MKIS becomes more advanced, its applications in the marketing mix become very specific to each marketing element.

\subsection{Research model}

In order to investigate the role of MKIS in service quality in Ethiopian industries, this study considered IT infrastructure, data-gathering or information-acquisition, information processing, and the use of information in different marketing-decision environments. The researchers followed the conceptual framework or research model shown in Figure 2. The model illustrates the interactions of data acquisition/gathering, IT infrastructure, and information processing with business function and service quality. In modern marketing thinking, MKIS is not limited to management, but includes other functional units in the organisation. As a result, measuring the constructs and dimensions of MKIS exhaustively is very difficult and complex $[32,16]$. In this research, the MKIS is represented by various constructs: data acquisition, IT infrastructure, and information processing as part of datagathering and information analysis; the business function as part of the marketing activities (which mainly include planning, decision-making, and implementation) [23, 16]. Based on the information obtained, the business function is expected to act in ways that increase service quality. So, if a firm's service is satisfactory, it should show itself as the effectiveness of the MKIS [4, 29]. It is also important to note, at this point, the contribution of MKIS in improving the effectiveness and efficiency of marketing and communication efforts $[15,32]$. 


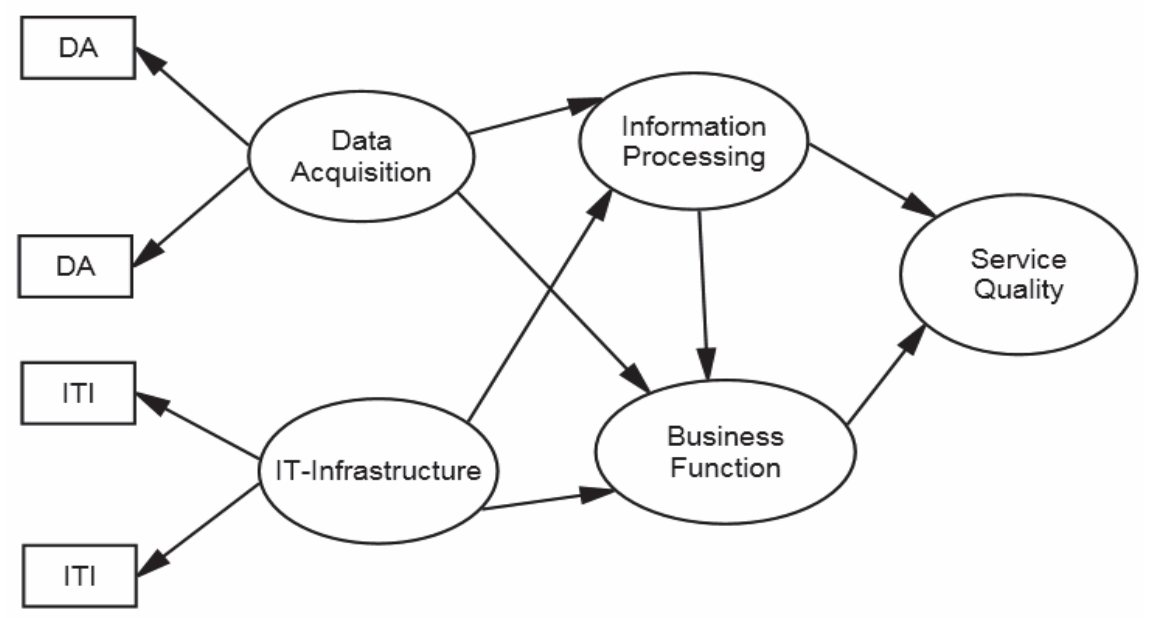

Figure 2: Research model

The authors characterised the presence of MKIS by the availability of IT infrastructure, information acquisition, information processing, and activities in the business function. The data collected was analysed using the available IT infrastructure for the purpose of decision-making in the business function for service quality. The research model shows that data acquisition and IT infrastructure have a direct impact on the information process and the business function; the information process has a direct effect on the business function and service quality; and the business function has a direct effect on service quality (Figure 2). Based on this, the following three research hypotheses are formulated:

$\mathrm{H}_{1}$ : Data acquisition and IT infrastructure have a positive impact on information processing and business function.

$\mathrm{H}_{2}$ : Information processing has a positive impact on business function and service quality.

$\mathrm{H}_{3}$ : Business function has a positive impact on service quality.

\subsection{Dimensions of MKIS and service quality}

MKIS is not limited to marketing management, but ranges from the strategic to the operational levels [16]. It is defined by many authors and scholars as a procedure and method for planning, analysis, and the presentation of information for use in marketing decisions [23, 36]. Moreover, different models are proposed for MKIS. Most can be classified into five categories according to their primary use $[23,36,15,16]$ : data gathering, data analysis, planning, decision-making, and implementation of marketing activities. In this research the dimensions of MKIS and service quality are briefly explained. The dimensions of MKIS considered in this study include some of the major ones identified by Jari [15], Parasuraman et al. [27], and Kotler [23].

Dimensions of MKIS. The dimensions of MKIS include data acquisition, IT infrastructure, information-processing, and activities in the business functions. They are adopted from the six MKIS groups in the classification of Jari [15] and modified to suit the model. In general, gathering information on the actual or potential market-place not only allows organisations to monitor trends and issues concerning their current customers, but also helps them to identify and profile potential customers and new markets. It also helps to keep track of the competition, their strategies, tactics, and future plans [2]. According to Moorman [25], information acquisition is the collection of primary or secondary information from organisational stakeholders. This may occur through formal or informal market surveys. The relevance of the collected data is also an important criterion that is always underlined during data acquisition. The data gathered at different data collection points includes data gathered from customers, competitors, and the marketing environment [16]. To account for this, the questionnaire in the section on data acquisition considered the data collected from the point of view of competitors, customers, sales points, distributors, and suppliers. 
The collected and processed data has to be stored in the organisation's data storage system and disseminated for use. In order to store, analyse, and disseminate the collected data, IT infrastructures such as hardware and software $[12,8]$ and networks are required. The collected data has to be processed to generate information and then disseminated among several users for decision-making [15]. The information-processing activities and their uses are studied in four categories [25]: information analysis, transmission, conceptual use, and instrumental use.

In most enterprises the problem lies not in how to get the data but in what to do with it, and how the data should be turned into useful information $[8,25]$ - that is, information analysis. Unless organisations have a system that evaluates and analyses the collected data, and then extracts and converts it into meaningful information, it is impossible to get the maximum benefit from it. Information transmission refers to the process of transmitting or disseminating information to various functional elements of the organisation. Moorman [25] stated that the information transmission process refers to the degree to which information is diffused among relevant users within an organisation. This process may occur formally through organised or structured dissemination, or informally through personal interactions.

Conceptual use is the indirect use of information in strategy-related actions in the business function [25]. Compared with instrumental use, conceptual use is more cognitive and affective in nature, and therefore less direct in its influence on marketing strategies and customer satisfaction. But the direct application of information - instrumental use - refers to the extent to which an organisation directly applies the information to a business function in order to influence marketing strategy-related actions [25].

The remaining dimension of MKIS is the business function. It represents that part of the MKIS concerned with planning, decision-making, and the implementation process in marketing activities.

Service quality is known to be based on many dimensions [18, 27]. Quality is an elusive and indistinct construct [27]. However, 'service quality' is more difficult to define than the quality of a manufacturing product. This research examines the functional aspects of service, although different scholars propose various dimensions [27]. The dimensions of service quality are adopted from the SERVQUIL model [26, 18]. Service quality is conceptualised using four different constructs [18]: assurance, reliability, responsiveness, and empathy. Tangibility is excluded, as it is included directly or indirectly in the IT infrastructure and business function. A SERVQUIL model is considered appropriate for measuring IS service quality $[19,29]$, and is also a useful tool for assessing service quality $[27,30]$.

\section{RESULTS}

Before evaluating the research model, the reliability of the modified and new items was tested carefully. In order to have a valid construct in the model, each of the items comprising the construct was checked to see if it was unidimensional. This in turn would help to produce a consistent result. Each construct was then evaluated using a separate factor analysis (FA), as reported in Table 1.

The model fit for each FA was evaluated using Tucker-Lewis's goodness-of-fit-index (TLI), Bentler's comparative-fit-index (CFI), and the goodness-of-fit index (GIF). Moreover, the root mean square residual (RMR) and the chi-square $(\chi 2)$ values were also reported in Table 1 as a reference for model fit. The FA suggested that all the items be retained for data acquisition and IT Infrastructure. The findings indicated that the data fit the model reasonably well $(\mathrm{GIF}=0.92, \mathrm{CFI}=0.75, \mathrm{TLI}=0.83$ for data acquisition, and $\mathrm{GIF}=0.89, \mathrm{CFI}=0.99$, $\mathrm{TLI}=0.99$ for IT infrastructure). The FA for information-processing retained a total of 23 items out of 30. The initial FA indicated bad fit with the model. But, based on the review and deletion of bad factor loading items, the FA suggested that 23 items be retained to assess information-processing. The FA for information-processing indicated that the model 
fits well $(\mathrm{GIF}=0.97, \mathrm{CIF}=0.99$ and $\mathrm{TLI}=0.99)$. In a similar way, the FA suggested 10 and 14 items to be retained for business function and service quality respectively. In both constructs the model fits well ( $\mathrm{GIF}=0.99, \mathrm{CIF}=0.91$ and $\mathrm{TLI}=0.95$ for business function, and $\mathrm{GIF}=0.95, \mathrm{CIF}=0.94$ and $\mathrm{TLI}=0.81$ for service quality). The RMRs of all the constructs are closer to zero, showing a perfect fit. The reliability test of the FA of each item or set of items under each construct is reported in the same table.

Table1: Summary statistics of the FA for the constructs (Varimax)

\begin{tabular}{|c|c|c|c|c|c|c|c|c|c|c|}
\hline & $\begin{array}{c}\text { \#of } \\
\text { Items* }\end{array}$ & Mean & $\begin{array}{l}\text { Std. } \\
\text { Dev. }\end{array}$ & Alpha & $\chi^{2}$ & $d f$ & GFI & $\mathrm{CFI}$ & TLI & RMR \\
\hline \multicolumn{11}{|l|}{ Data acquisition } \\
\hline Data acquisition & $6(6)$ & 4.02 & 0.33 & 0.74 & 27.9 & 9 & .92 & .75 & .83 & .03 \\
\hline \multicolumn{11}{|l|}{ IT infrastructure } \\
\hline IT infrastructure & $4(4)$ & 3.28 & 0.87 & 0.83 & 2.02 & 2 & .89 & .99 & .99 & .02 \\
\hline \multicolumn{11}{|c|}{ Information process } \\
\hline Info. analysis & $3(5)$ & 3.52 & 0.81 & 0.54 & \multirow{4}{*}{2.34} & \multirow{4}{*}{2} & \multirow{4}{*}{.97} & \multirow{4}{*}{.99} & \multirow{4}{*}{.99} & \multirow{4}{*}{.01} \\
\hline Conceptual use & $5(5)$ & 3.58 & 0.76 & 0.75 & & & & & & \\
\hline Instrumental use & $11(14)$ & 3.86 & 0.59 & 0.88 & & & & & & \\
\hline Info. transmission & $4(6)$ & 3.88 & 0.69 & 0.64 & & & & & & \\
\hline \multicolumn{11}{|l|}{ Business function } \\
\hline Planning & $3(4)$ & 2.33 & 0.25 & 0.63 & \multirow{3}{*}{3.45} & \multirow{3}{*}{2} & \multirow{3}{*}{.99} & \multirow{3}{*}{.91} & \multirow{3}{*}{.95} & \multirow{3}{*}{.02} \\
\hline Decision-making & $4(5)$ & 2.85 & 0.53 & 0.73 & & & & & & \\
\hline Implementation & $3(5)$ & 2.91 & 0.23 & 0.74 & & & & & & \\
\hline \multicolumn{11}{|l|}{ Service quality } \\
\hline Empathy & $5(7)$ & 2.94 & 0.46 & 0.66 & \multirow{4}{*}{4.9} & \multirow{4}{*}{2} & \multirow{4}{*}{.95} & \multirow{4}{*}{.94} & \multirow{4}{*}{.81} & \multirow{4}{*}{.03} \\
\hline Reliability & $3(5)$ & 3.01 & 0.33 & 0.65 & & & & & & \\
\hline Responsiveness & $3(3)$ & 2.63 & 0.14 & 0.58 & & & & & & \\
\hline Assurance & $3(5)$ & 2.97 & 0.10 & 0.69 & & & & & & \\
\hline
\end{tabular}

According to the analysis, Cronbach's Alpha - a measure of internal consistency based on the average inter-item-correlations - is also evaluated. Though the commonly accepted level of Alpha is 0.60 [17], the finding showed that, apart from one construct (that for information analysis with alpha $\leq 0.60$ ), all have a Cronbach's Alpha value $\geq 0.6$. Moreover, all of the items under each construct have a factor loading $\geq 0.50$ and correlated-item-total correlation $\geq 0.30$ [7]. In attempting to address the data collection aspect and the presence of IT infrastructure in Ethiopian industries, the descriptive analysis was conducted before the path analysis, and is shown in Table 2.

The findings indicated that sales points and customer satisfaction, with the highest mean and the lowest standard deviation, were equally found to be the most important data collection points compared with others. Competitors' price was the second most important data collection point for Ethiopian industries, followed by distribution channel and advertising. With regard to IT infrastructure, most companies do not have a computerised IS. Those that do have a computerised IS do not regularly update their software and therefore suffer inadequate network infrastructures and poor connectivity with their outlying offices. A non-computerised information system, with the highest mean (3.95) and lowest standard deviation (1.16), was the dominant information process used in most of the industries. 
Table2: Statistical summary of the data collection point and IT infrastructures

\begin{tabular}{|c|c|c|c|c|c|c|c|c|c|c|}
\hline & \multicolumn{6}{|c|}{ Data gathering/information acquisition } & \multicolumn{4}{|c|}{ IT infrastructures } \\
\hline & 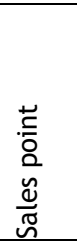 & 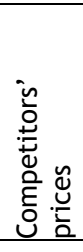 & 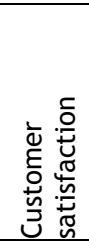 & 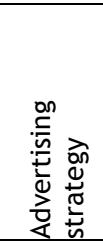 & 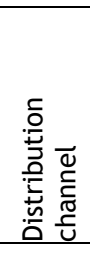 & 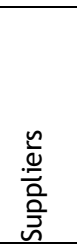 & 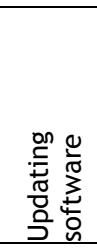 & 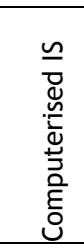 & 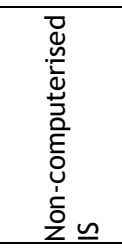 & 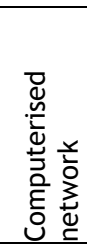 \\
\hline Valid & 41 & 41 & 41 & 37 & 37 & 38 & 34 & 36 & 41 & 36 \\
\hline Mean & 4.51 & 4.12 & 4.51 & 3.81 & 3.92 & 3.58 & 2.85 & 3.33 & 3.95 & 2.42 \\
\hline Std. dev. & 0.78 & 1.19 & 0.78 & 1.05 & 1.21 & 1.31 & 1.52 & 1.59 & 1.16 & 1.31 \\
\hline Min & 1 & 1 & 1 & 1 & 1 & 1 & 1 & 1 & 1 & 1 \\
\hline $\operatorname{Max}$ & 5 & 5 & 5 & 5 & 5 & 5 & 5 & 5 & 5 & 5 \\
\hline Sum & 185 & 169 & 185 & 141 & 145 & 136 & 97 & 120 & 162 & 87 \\
\hline Total & 42 & 42 & 42 & 42 & 42 & 42 & 42 & 42 & 42 & 42 \\
\hline
\end{tabular}

Furthermore, the information processing in Table 1 indicates that the information analysis (with mean 3.52 and std. dev. 0.81) is relatively weak, but above the median (3). The information transmission (mean 3.88 and std. dev. 0.69) and the direct use of information (instrumental use with mean 3.86) in decision-making in Ethiopian industries are also found to be good, but there is a relatively weak indirect use of the information (conceptual use with mean 3.58 and std. dev. 0.76).

The research model is tested using path analysis and the result is shown in Table 3 . The findings indicated that the data fits the model reasonably well with GIF $0.89, \mathrm{CFI}=0.92$, $T L I=0.43, R M R=0.07$, but with a low TLI value. The reported $R^{2}$ values estimate that the predictors of IP, BF, and SQ explain $31.9 \%, 66.0 \%$, and $47.0 \%$ of its variance respectively. The findings indicated that - except for the path coefficient leading from IT infrastructure to business function - all the path coefficients are positive, indicating that there is a positive relationship among them. Moreover, the direct relationships between data acquisition and information processing $\left(\gamma_{11}=0.51\right)$, IT infrastructure and information processing $\left(\gamma_{12}=0.50\right)$, information processing and business function $\left(\beta_{11}=0.68\right)$, and information processing and service quality $\left(\beta_{12}=0.38\right)$ are all found to be positive and statistically significant; they supported $\mathrm{H}_{1 \text { \&2 }}$. Both data acquisition and IT infrastructure are non-significant predictors of business function, but have an indirect effect on business function through the information process. The negative relationship between data acquisition and business function $\left(\Upsilon_{21}=-0.07\right)$ is an unexpected result. The influence of business function on service quality is found to be insignificant $\left(\beta_{21}=0.23\right)$ - it failed to support $\mathrm{H}_{3}$. However, there is a strongly positive correlation $(r=0.61)$ between service quality and business function.

\section{DISCUSSION}

The findings of this study show that most data in Ethiopian industries, collected from the point of view of customers and IT infrastructure, is dominated by a non-computerised information system. However, both data acquisition and IT infrastructure support information processing, which subsequently strongly supports the business function activities. The path leading from data acquisition to information processing is longer than the path leading from IT infrastructure to information processing. The other finding of the study is the positive influence of data acquisition and IT infrastructure on information processing in Ethiopian industries. This is consistent with Jari et al. [16] and Kettinger et al. [20]. 
Table3: The result of structural equation model testing

\begin{tabular}{llccc}
\hline \multicolumn{2}{c}{ Path } & \multicolumn{1}{l}{ Estimate } & Standard error & $\mathrm{R}^{2}$ \\
\hline $\mathrm{Y}_{11}$ & $\mathrm{IP}<---\mathrm{DA}$ & $0.51(0.00)^{*}$ & 0.10 & $0.32(\mathrm{IP})$ \\
$\mathrm{Y}_{12}$ & $\mathrm{IP}<---\mathrm{ITI}$ & $0.38(0.00)$ & 0.08 & \\
$\mathrm{Y}_{21}$ & $\mathrm{BF}<---\mathrm{ITI}$ & $-0.07(0.69)$ & 0.06 & \\
$\mathrm{Y}_{22}$ & $\mathrm{BF}<---\mathrm{DA}$ & $0.03(0.82)$ & 0.06 & $0.66(\mathrm{BF})$ \\
$\beta_{11}$ & $\mathrm{BF}<---\mathrm{IP}$ & $0.68(0.00)$ & 0.16 & \\
$\beta_{12}$ & $\mathrm{SQ}<---\mathrm{IP}$ & $0.51(0.00)$ & 0.20 & $0.47(\mathrm{SQ})$ \\
$\beta_{21}$ & $\mathrm{SQ}<---\mathrm{BF}$ & $0.23(0.14)$ & 0.23 &
\end{tabular}

*(p-value $) ; \chi 2=7.96, \mathrm{df}=2, \mathrm{P}=0.019 ; \mathrm{GIF} 0.89, \mathrm{CFI}=0.92, \mathrm{TLI}=0.43, \mathrm{RMR}=0.07$

Correlation matrix

$\begin{array}{llllll} & \text { DA } & \text { ITI } & \text { IP } & \text { BF } & \text { SQ } \\ \text { DA } & - & & & & \\ \text { ITI } & -0.01 & - & & & \\ \text { IP } & 0.45^{* *} & 0.33^{*} & - & & \\ \text { BF } & 0.31 & 0.31 & 0.81^{* *} & - & \\ \text { SQ } & -0.20 & 0.21 & 0.68^{* *} & 0.61^{* *} & -\end{array}$

Note: *All significant $p<0.05,{ }^{* *}$ all significant $p<0.01 ; D A=$ Data acquisition, ITI=IT infrastructures, $\mathrm{IP}=$ Information process, $\mathrm{BF}=$ Business functions, and $\mathrm{SQ}=$ Service quality

The study also shows the influence of information processing on business function and service quality. The direct effect of information processing on service quality and business function is comparable. However, information processing had a larger effect on business function than on service quality. This finding shows that the information processed is consumed more for the organisation's internal operations (business functions for planning, decision-making, and implementation) than to improve service quality. The findings also suggest that business function does not have an important influence on service quality in Ethiopian industries. This contradicts the results of George et al. [11], Pitt et al. [29], and Spiros et al. [32]; but it is in line with the findings of the Ethiopian Science and Technology Commission [9]. However, the findings that business function has no effect on service quality should be taken with caution. The small sample size may have resulted in a nonsignificant relationship. Future research is needed to confirm this.

\section{CONCLUSION}

Information systems, in one form or another, may exist in organisations. What matters more, however, is that the existing information systems for business functions are used to fulfill their marketing needs. Despite the current weakness of their IT infrastructure, most Ethiopian industries have relatively good information processing systems. This strongly supports both business function and service quality. In a few of the industries where there is no established computerised information system, the data storage and information processing capacity is negatively affected. Based on the findings of this study, we can conclude that the information processing systems of most industries support business function more than they do service quality. On the other hand, business function does not 
support service quality very well. This indicates that many organisations in the service and production sectors in Ethiopia use information and apply it only at a conceptual level.

\section{REFERENCES}

[1] Africa Recovery. 1999. Building Blocks for Communications, 13(4), 17. (Part of a special feature on information technology).

[2] Ahituv, N. \& Machilin, J. 1998. Environmental scanning and information systems in relation to success in introducing new products. Journal of Information \& Management, 33(4), 201-211.

[3] Albert C., Arthur, H. \& Pierre R. 2000. Service quality and satisfaction - the moderating role of value. European Journal of Marketing, 34(11/12), 338-1352.

[4] Bharatia, P. \& Bergb, D. 2005. Service quality from the other side: Information systems management at Duquesne Light. International Journal of Information Management, 25(4), 67-380.

[5] Barrett, M. \& Susan, S. 2003. Electronic trading and the process of globalization in traditional futures exchanges: A temporal perspective. European Journal of Information Systems, 13(1), 6579.

[6] Daniel, K. 2009. Industrial management and engineering economy: An introduction to industrial engineering. Addis Ababa University Press.

[7] Field, A. 2009. Discovering statistics using SPSS ( $2^{\text {nd }}$ ed.), SAGE Publications, London.

[8] Bunchua, E.K. 2004. Marketing information system lecture note, Department of Marketing, Faculty of Business Administration, Chiang Mai University, accessed November 2010, http://freedownload.is/ppt/705342-marketing-information-system-2-information-systemsconcept-359351.html.

[9] Ethiopian Science and Technology Commission. 1987. A survey on library, information and documentation activities in Ethiopia.

[10] Franes, B. \& Stephen, P. 2000. Principles of marketing ( $2^{\text {nd }}$ ed.), Prentice Hall.

[11] George, G. \& Kalliopi, C. 2006. The impact of design characteristics and support services on the effectiveness of marketing information systems: An empirical investigation, Review of Business Information Systems, 10(2), 91-104.

[12] Gordon, B.D. \& Margrethe, H.O. 1974. Management information system conceptual foundations, structure and development $\left(2^{\text {nd }}\right.$ ed. $)$, McGraw-Hill.

[13] Harrison, A. 2004. Ethiopian ICT companies demand equal incentives as other service delivery sectors, Ethiopian Reporter, August 11/08/2004.

[14] Hipkin, I. 2004. Determining technology strategy in developing countries, Omega, 32(3), 245-260.

[15] Jari, M.T. 1995. Information systems in marketing identifying opportunities for new applications. European Journals of Marketing, 29(1), 8-26.

[16] Jari, M.T. \& Timo, S. 1995. MkIS support for the marketing management process: Perceived improvements for marketing management. Marketing Intelligence \& Planning, 13(1), 8-27.

[17] Joseph, F.H., William, C.B. \& Barry, J.B. 2010. Multivariate data analysis ( $7^{\text {th }}$ ed.), Pearson Education / Prentice Hall.

[18] Kang, G. \& James, J. 2004. Service quality dimensions: An examination of Grönroos's service quality model. Managing Service Quality, 14(4), 266-277.

[19] Kettinger, W.J. \& Lee, C.C. 1994. Perceived service quality and user satisfaction with the information service function. Decision Sciences, 25(6), 737-766.

[20] Kettinger, W.J, Lee, C.C. \& Lee, S. 1995. Global measures of information service quality: A cross-national study. Decision Sciences, 26(5), 569-588.

[21] Kotler, P. \& Armstrong, G. 1996. Principles of marketing ( $7^{\text {th }}$ ed.), Prentice-Hall International.

[22] Kotler, P. 1980. Marketing management: Analysis, planning, and control (4 $4^{\text {th }}$ ed.), Englewood Cliffs, N.J., Prentice-Hall.

[23] Kotler, P. 1994. Marketing management - Analysis, planning, implementation and control $\left(9^{\text {th }}\right.$ ed.), Prentice-Hall International, London.

[24] Li, Y. 1995. Marketing information systems in the top U.S. companies: A longitudinal analysis. Journal of Information \& Management, 28(1), 13-31.

[25] Moorman, C. 1995. Organizational market information processes: Cultural antecedents and new product outcomes. Journal of Marketing Research, Vol. XXXII, 318-335.

[26] Niza, B., Annuar, S., Fazly, B., Ismail, M. \& Aimah, N. 2010. Service quality and customer satisfaction: The public sector perspective, International Conference on Business and Economic Research, paper185, Hilton Hotel-Kuching Sarawak, 15-16 March, Malaysia.

[27] Parasuraman, A., Zeithaml, V.A. \& Berry, L.L. 1985. A conceptual model of service quality and its implications for future research. Journal of Marketing, 49, 41-45.

[28] Parasuraman, A., Zeithaml, V.A. \& Berry, L.L. 1993. Research note: More on improving service quality measurement. Journal of Retailing, 69(1), 140-147.

[29] Pitt, L.F., Watson, R.T. \& Kavan, C.B. 1995. Service quality: A measure of information system effectiveness. MIS Quarterly, 19(2), 173-187. 
[30] Pitt, L.F., Watson, R.T. \& Kavan, C.B. 1997. A measuring of information system service quality: Concerns for a complete canvas. MIS Quarterly, 21(2), 209-221.

[31] Spiros, P.G. \& Kalliopi, C. 2007. Measuring the effectiveness of marketing information systems: An empirically validated instrument. Journal of Marketing Intelligence \& Planning, 25(6), 612-631.

[32] Terrence, V., Denise, D. \& Geoffrey, L. 1995. Marketing information systems for consumer products companies: A management overview. Journal of Consumer Marketing, 12(5), 16-36.

[33] Teferie, K. 1989. Summary of information documentation in Ethiopia. A paper presented at the seminar on Management of Scientific, Technological and Socio-Economic Information Systems and Networks, Moscow, USSR.

[34] UNDP Ethiopia Newsletter. 2001. Ethiopia in the knowledge age. A conference on information and Communication Technologies for Development, News and Publication, 18-20 June, Addis Ababa, Ethiopia.

[35] Wierenga, B., Gerrit, V. \& Staelin, R. 1999. The success of marketing management support systems. Marketing Science, 18(3), 196-207.

[36] Wierenga, B. \& Van Bruggen. G.V. 2000. Marketing management support systems: Principles, tools and implementation. Kluwer Academic Publishers.

[37] Gourvennec, Y. A. 1996. Visionary marketing: From the understanding of complex customers to the design of marketing-orientated information systems (M.O.I.S.), 1-58: http: / /visionarymarketing.com

[38] Yao, C. \& Joe, Z. 2004. Measuring information technology's indirect impact on firm performance. Journal of Information Technology and Management, 5(1-2), 9-22.

[39] Zewede, S. 1999. Promoting micro and small enterprises (MSEs) within the development context of Ethiopia. Paper presented at the Workshop on Regional Development Policy and Data System, in the Ministry of Economic Development and Cooperation, July 26-30, Nazaret, Ethiopia. 